\title{
Muralf
}

INTERNACIONAL

\section{A latin american regionalism in the XXI century: an ongoing interactive game of resistance and cooperation \\ El regionalismo latinoamericano en el siglo $X X I:$ un juego interactivo de resistencia y cooperación RITA GIACALONE ${ }^{1}$}

Abstract: Our argument is that in the XXI century resistance and cooperation formed the central axis of relations among Latin American regional agreements and helped promote an interactive game among them. Though threats posed by the international system exerted influence on the game, this article looks at how peripheral nations in Latin America reacted to actions of other peripheral nations in the same region rather than to actions of central powers. We identify the main factors behind neighboring nations' resistance to different regional agreements, place them in an interactive study of Latin American regionalism (2000-2018), and discuss how decisions taken in a regional agreement influence other regional actors' future decisions, combining game theory and discourse analysis. The article contributes supporting arguments to the literature that stresses actorness (agency) by developing nations.

Keywords: Regionalism; interactive game; Latin America
Recebido em:

16 de Julho de 2018

Received on:

July 16, 2018

Aceito em:

6 de Outubro de 2018

Accepted on:

Octubre 6, 2018

DOI: 10.12957/rmi.2018.36079

Resumen: Se argumenta que en el siglo XXI resistencia y cooperación fueron el eje central de la interacción entre acuerdos regionales latinoamericanos y contribuyeron a impulsar un juego interactivo entre ellos. Aunque las amenazas del contexto internacional ejercieron influencia en el juego, se analiza cómo naciones periféricas latinoamericanas reaccionaron a acciones de otras naciones periféricas de su región antes que a las de naciones desarrolladas. Primero, se identifica los factores detrás de la resistencia de sus vecinos a distintos acuerdos regionales, luego se los ubica en un estudio longitudinal de la interacción entre ellos (2000-2018) y se discute de qué forma las decisiones tomadas dentro de un acuerdo influyeron sobre las decisiones de otros actores regionales, combinando teoría del juego y análisis del discurso. El artículo aporta argumentos a la literatura que enfatiza la agencia de las naciones en desarrollo en las Relaciones Internacionales.

Palabras clave: regionalismo; juego interactivo; América Latina

${ }^{1}$ Doctora en Historia por Indiana University. Profesora-Investigadora, Facultad de Ciencias Económicas y Sociales, Universidad de Los Andes. Dirección Postal: Latin American Research Centre, University of Calgary, Social Sciences 004, 2500 University Drive NW Calgary, Alberta, Canada T2N 1N4. Email: ritagiacalone@ hotmail.com ORCID: 0000-0003-4989-4503 


\section{Introdução}

Resistance and co-operation were at the center of interactions among Latin American regional agreements (regionalism) since 2000 developing into an interactive game. Though the threats posed by the international system - mega trade deals, protectionism, low growth and diminished importance of Latin American trade - influenced the game, this article looks at how peripheral nations react to actions of other peripheral nations rather than to actions of central powers (Escudé 2015, p. 45). The first section analyzes regional agreements from the vantage point of their neighbors' resistance ${ }^{2}$; the second presents a longitudinal game analysis of interactions among them in Latin America (2000-2018), and the third discusses our findings. We identify the main factors behind resistance, place them in an interactive study of regionalism, and discuss how actors' decisions influence other actors' future decisions.

\footnotetext{
${ }^{2}$ Resistance means not accepting a decision or process and does not preclude collaborating in other aspects. When resistance covers every element of a bilateral relationship, it turns to confrontation or opposition. Cooperation implies that both actors help each other or associate for a common benefit.
}

This empirical study based on secondary material, discourse analysis, and statistical information contributes supporting material to the literature that stresses the agency of developing nations, and regionalism as a foreign policy mechanism to construct support networks and gain parcels of power for their promoting governments ${ }^{3}$.

\section{I.1.Brazilian regionalism and resistance}

Brazilian regionalism is asymmetrical because there are deep material differences between Brazil and the rest, its government uses the region as a platform to project itself globally and its partners are unable to balance Brazil (Beeson, 2010). While in South EastAsia the high degree of institutionalized regional organizations contains China's asymmetry (Beeson, 2010), in MERCOSUR and UNASUR Brazil imposes a low level of institutionalization. Brazilian business can compete globally without resorting to MERCOSUR, but Brazil uses

\footnotetext{
${ }^{3}$ A discussion of the theoretical literature on regionalism falls outside the scope of this article, but our analysis follows studies that explore the contestation of regional powers and their regional projects by secondary actors and its consequences for a region's balance of power (Flemes/Whener, 2012), emphasizing relations among actors and their decisions.
} 


\section{Muralf}

INTERNACIONAL

regionalism to build and maintain control of regional markets. In 2000, Brazilian agroindustry value chains were national and in soy, cereals, and beef competed with those of Argentina, Uruguay, and Paraguay (Bisang; Gutman, 2000), a situation that deepened during the exporting boom (O’Connor, 2010: 58).

While Brazil promoted free trade agriculture at the World Trade Organization, it kept a closed vision of MERCOSUR and South America that explains its opposition to the Free Trade Area of the Americas (FTAA). Even if political autonomy vis-à-vis the US was a Brazilian motivation, after the negotiation failed, Brazil consolidated itself as a major regional provider of goods, services, and investments protected by preferential tariffs. Consequently, between 2002 and 2011, its exports to South America went from US\$ 7.4 billion to US\$ 45.2 billion (Pinheiro; Gaio 2014, p. 16).

Prys (2010) and Beeson (2010) point out that Brazil's reluctance to deliver economic compensation to MERCOSUR members compounds its asymmetry. Flemes and Wehner (2012) add that Brazil is unwilling to develop democratic regional organizations because they may compromise its national projection. Even Malamud
Mural Internacional

V. 9 | N. 1

JAN-JUN 2018
(2016), who thinks that Brazil offers compensations such as regional order and stability, accepts that Brazil does not have enough resources for compensating partners. Though Pinheiro and Gaio (2014: 26) posit that Brazil uses cooperation projects by its National Development Bank (BNDES) to compensate for asymmetry, the fact that its credits abroad go to Brazilian business, individuals and organizations ensures that the benefits accrued get back to Brazil.

Examples of resistance to Brazilian regionalism are Chile rejection of becoming full member of MERCOSUR and Venezuela's establishment of the Bolivarian Alliance for Our America (ALBA), in parallel with the South American Community (SAC/later UNASUR) promoted by Brazil. Economic explanations of Chile opposition stress that MERCOSUR's external tariffs were double those of Chile, the group was unwilling to lower them, and Chile was more interested in an agreement with the US due to the size of the American market (Manger 2009, pp. 163-165, 171-174). Economy Minister José de Gregorio also declared that Chile "would not think of sacrificing our trade autonomy" (Lapp 2012, p. 152), a reference to MERCOSUR decision (2000) that any future trade negotiation of members 
would have to be done with the group. And, as MERCOSUR's economies were more volatile than the Chilean one, integration with MERCOSUR would raise the degree to which volatility could be transmitted to Chile's economy, complicate production and export plans, and harm Chile's international credibility (Schiff 2002, p. $35)$.

But Chile was also aware of the fact that MERCOSUR external tariffs protected Brazilian regional interests (Schiff 2002, p. 9). The asymmetric nature of MERCOSUR and the centrality of Brazilian interests influenced the Chilean decision because, even if mentions of MERCOSUR in government discourse were positive (Van Klaveren, 1998), entry to MERCOSUR implied changing Chilean economic policies since the 1980s and submitting to the economic interests of Brazil. Entry to an exclusive, protectionist and asymmetric regional agreement represented a risk, and the following Michelle Bachelet administration maintained that position despite political affinity with the Lula da Silva Brazilian government ${ }^{4}$.

\footnotetext{
4 Resistance to Brazilian asymmetrical regionalism developed within MERCOSUR too. Contemporary accounts have recorded that Argentina opposed the reform of the Security Council of the United Nations (see Foreign Policy Minister Rafael Bielsa's statements to La Nación October
}

Chile did not resist, however, the Brazilian-sponsored SAC, a more relaxed forum, but insisted in including preservation of sovereignty, consensus decision-making and Article 13 of the UNASUR treaty (2008) establishing that the adoption of a decision by consensus does not imply that it is mandatory to apply it. Perception of a Venezuelan threat pushed Chile to include this article (Flisfisch (2011, p. 133).

Though presented as a counter proposal to the FTAA, ALBA competed with the Brazilian regional project based on Venezuelan financial resources generated by the oil boom (2003-2008) (Flemes; Wojczewski 2011, p.10). ALBA did not have the approval of Brazil, which subscribed the notion that the integration process should proceed through MERCOSUR (Giacalone, 2008, pp. 26-31), but attracted small nations (Bolivia, Ecuador), one of which (Bolivia) was in Brazilian area of influence.

11, 2004; Cárdenas, 2005; Diamint, 2005), considered that the founding of SAC meant "the end of MERCOSUR" (Cisneros 2005, pp. 119-120), and President Nestor Kirchner claimed that MERCOSUR benefits "could not go in an only direction" because none of its members was so big "as to be able to escape its regional destiny" (quoted in Colombo 2011, p. 163). 


\section{Muralf}

INTERNACIONAL

Though in 2006 Venezuela left the Andean Community (CAN) to apply for MERCOSUR membership, its government kept stressing that MERCOSUR and CAN should disappear (Venezuela. MRE, 2006). Venezuela asked for "reformatting" MERCOSUR (REUTERS/EFE, 2006) and considered that SAC should move beyond a CAN-MERCOSUR trade zone to become a political and security organization -- whose control Venezuela should secure and expand through ALBA to all Latin America.

Since 2005, resistance to Brazilian regionalism diminished. In those years, the commodities' exporting boom benefited all South American nations that could tolerate Brazilian asymmetry if it did not interfere with their economic growth. Intra-regional relations in SAC/UNASUR show a consistent pattern of Brazilian moderate proposals defeating Venezuelan radical ones with the vote of most South American governments (Quintanar, 2012). As, from 2004 on, Venezuela pushed forward an aggressive regional policy and was perceived as a threat, diminishing resistance to Brazil can be linked to the feeling that it was the only regional actor with power to restrain Venezuela.
Mural Internacional

V. 9 |N. 1

JAN-JUN 2018

In the 2010s, the end of the commodities boom fostered economic uncertainty and an increase in trade with China gave added value to the geographical location of Chile, Colombia, México, and Perú. Their governments favored open regionalism and established the PA (2012) based on its principles. But they have also clashed with Venezuela/ALBA before, so the new regional agreement combined their individual resistance to asymmetrical Brazilian regionalism and to the Venezuelan political project (Flisfisch, 2011).

\section{I.2.Venezuelan Regionalism and} Neighbours' Resistance

ALBA combines ideology with economic incentives (Vieira; Alden 2011, p. 525; Malamud, 2016) because Venezuela promotes the political and ideological unification of members around anti-imperialism, antiAmericanism, and anti-neoliberalism, and backs this with the use of material incentives. ALBA's combination of a political/ideological alliance with oil and financial assistance (Girvan, 2008; Diamint 2013) separates it from other Latin American regionalisms because the second element makes possible the first objective. Accordingly, Venezuelan regionalism is an example of transactional regionalism (Northhouse, 
2001), implying that without oil resources the agreement would not have developed beyond bilateral agreements with like-minded governments (Cuba, Bolivia, Nicaragua).

Even relations with governments ideologically close to Venezuela have transactional dimensions (i.e. they include bargaining elements of an economic nature). The Cuba-Venezuela treaty includes exports of Cuban goods and services (physicians, intelligence personnel) to Venezuela in exchange for subsidized oil that can be re-exported after being processed in Venezuelan refineries in the island, ${ }^{5}$ and Cuban State companies obtain preferential contracts in ALBA nations. Nicaragua's adherence to ALBA fostered the Venezuelan cancellation of its US \$ 31.8 million bilateral debt (Muhr, 2010).

Venezuelan regionalism distributes positive retributions to followers (Northouse 2001), but this makes it necessary to concentrate on short and medium range objectives with high profile rather than ideological transformation. Followers' needs and circumstances became more important than Venezuelan ideological offer (Vega 2008, pp. 130-131). Summit meetings

\footnotetext{
${ }^{5}$ Portions of Petrocaribe bills convert into soft credits for development projects and construction of Venezuelan oil facilities in the Caribbean (Kirton, 2014).
}

declarations show the escalation of ideological proactivity (Milanese, 2007) until 2008-2009 followed by lack of development and a marked defensive position since 2013.

Transactional regionalism limits became apparent when oil prices fell in 2008 and 2014, and Venezuela went from creditor nation to debtor one. In the first case, the political closeness to Venezuela of Honduras (2009) and Paraguay (2012) governments determined domestic reactions that ended changing those governments. In 2014, Venezuela reduced Petrocaribe financial assistance, and promoted its transformation into an economic complementary trade zone (ACE 70) of ALADI, instead of the previous more open format of Petrocaribe ${ }^{6}$ (SELA, 2013, 2014). This action suggests a diminished Venezuelan capacity to maintain its role of buyer and financier of last resort for allies and followers.

After 2013, ALBA became a defensive mechanism to secure votes in regional organizations and prevent sanctions against Venezuela. Though the oil boom ended, highly indebted Caribbean governments need to support Venezuela because their newly constructed

\footnotetext{
${ }^{6}$ Previously, Venezuela allowed tariff-free entry of goods from Petrocaribe nations to pay for their oil bills. An ACE diminishes import tariffs but does not wholly abolish them.
} 


\section{Muralf}

INTERNACIONAL
Mural Internacional

V. 9 | N. 1

JAN-JUN 2018 facilities process Venezuelan heavy oil and will be inoperative if it stops coming (Kirton, 2014). Debts incurred under Petrocaribe are also a lever to get support for Venezuela (Girvan, 2008).

Resistance to ALBA came from Mexico and Colombia, which had established the Group of Three with Venezuela in the 1990s, when the three governments wanted to lock in their economic reforms and enlarge market access. Cooperation ended after Hugo Chavez, leader of a 1992 failed military coup, became president of Venezuela in 1999 with a civil-military coalition of the left opposing economic reforms and proWestern foreign policy.

In 2005, Mexican President Vicente Fox and Chavez clashed over the FTAA negotiation, and the Venezuelan president called Fox "a puppy of the Empire [the US]" (BBC, 2005). ALBA interpreted the subsequent conflict as a clash not with Mexico but with the US pretension to impose free trade in Latin America (Origen del conflicto MéxicoVenezuela, 2005). In the following years, this became an ALBA trait and any resistance was equated with extraregional interference. By depriving opposing actors of agency, ALBA aimed at attributing it exclusively to itself. The conflict eased out when
Mexico lost interest in the region after the failure of the FTAA negotiation.

Colombian resistance lasted longer than Mexico's because the risks posed by ALBA were bigger. The key element was Venezuelan support for the Fuerzas Armadas de Colombia (FARC) and other guerrilla groups. Drug trafficking, kidnapping and extortion in the Colombian-Venezuelan frontier increased after the arrival of Chavez to power. According to The ICG Latin American Report $\mathrm{N}^{\circ} 9$ (2004), the FARC negotiated the end of those activities in the border in exchange for de facto sanctuary in Venezuelan frontier states whose governments were granted to military officers close to Chavez to guarantee the compromise (Kornblith, 2004). This Venezuelaguerrilla association added fuel to Colombian resistance to ALBA due to their opposing development models and ideological nature.

Colombian resistance began with the detention in Venezuela of the so-called foreign minister of the FARC (2004), by Venezuelan army officers enticed by a reward from Bogota. In 2008, the Colombian bombing of a FARC camp in Ecuador led to the capture of compromising information about Venezuelan-FARC relations (Alegría; Arroyo, 2010), and Venezuela retaliated 
applying economic sanctions to Colombia. Bilateral conflict in the 2000s led to interruption of trade, public threats of employing military force, a de facto embargo of payment for Colombian imports (2010), and expulsion of Colombian nationals from Venezuela (2015). After the creation of the South American Defence Council (SADC) (2009), that rejected the presence of illegal armed groups in South America whatever their origin and ideology, Venezuela moderated its position and supported negotiation between the Colombian government and the FARC (Torrijos, 2009, p. 183) ${ }^{7}$.

Venezuela's neighbours resisted ALBA because Venezuelan financial assistance helped support opposition political parties and movements in them and strengthened their chances of winning power (Illera 2005, pp. 217, 219). Thus, resistance has links with ALBA's ideological aspects but also with its interference in the domestic politics of neighbouring countries.

\section{I.3.Chilean Regionalism and Neighbours' Resistance}

\footnotetext{
${ }^{7}$ Roca (2009) and Sanahuja (2010) consider that SADC permitted Brazil to moderate Venezuela by means of controlling its military expenditures and gathering information about its activities.
}

A pragmatic emphasis on global competitiveness promoted by Chile (Daniels 2015, p. 175) explain the foundation of the Pacific Alliance (PA) in 2012. By means of PA Chile, Colombia, Mexico, and Peru branded themselves as "good economies" compared to more State-oriented ALBA ones that by extension became "bad economies" (Nolte, 2016). Prerequisites like respect of democracy, human rights, and the state of law provided its political foundation together with active participation of the private sector, placing the agreement in opposition to ALBA. Previously, the Latin American Pacific Arc (made up by Colombia, Perú, Chile, Ecuador, El Salvador, Guatemala, Honduras, México, Panamá, 2007) supported similar principles.

Resistance to Chilean regionalism came from neighbors that felt marginalized by Chile's economic growth and opposed its neoliberal development model. In Argentina, resistance took the form of opposition to the negotiation of the FTAA that Chile supported (Mullins, 2006). Boskin (2013) encapsulates the situation of Chile and Argentina in the 2000s by asking: "Why does Chile prosper while neighbouring Argentina flounders?", in light of the fact that a century before Argentina was growing at a faster rate. Argentina's displacement from a stronger economic 


\section{Muralf}

INTERNACIONAL
Mural Internacional

V. $9 \mid$ N. 1

JAN-JUN 2018 position influenced resistance to Chile by linking its success to obsequious behaviour towards developed nations, and assuming Argentina became penalized for not being obsequious (Jarroud, 2014).

If Argentine resistance to Chile's pragmatic regionalism was sporadic, Bolivian resistance was continuous and resulted from a history of conflicts. Since 1978 when Peru rejected the option of a Bolivian corridor to the sea along its border with Chile, Chile has rejected a corridor that would divide Chilean territory (Mullins, 2006). In 2013, Bolivia presented its case to the International Court of Justice and justified its demand with the need to have access to the sea to diminish dependence on trade with Brazil and Chile (Armstrong, 2010, p.4).

The PA divided MERCOSUR -Argentina and Brazil resisted it, while Paraguay and Uruguay obtained observer status. In semi-official statements Brazil accused PA of being an irrelevant "marketing device". This resulted from the Brazilian perception of the PA as a Mexican intrusion in its sphere of influence rather than a USsponsored movement (Giacalone, 2013). It also contradicted the Brazilian project of a "wider MERCOSUR" (MERCOSUR ampliado) incorporating
South American nations with the aim of establishing a CAN-MERCOSUR trade zone. In practice, it only led to Venezuela and Bolivia entering MERCOSUR without renouncing ALBA membership.

Regardless the fact if the PA resulted from a defensive alliance of like-minded governments to promote their economic model or was a decision to balance ALBA, Argentina considered the agreement an instrument of US intervention to undermine Latin America's sovereignty (Narvaez, 2015). Official Argentine discourse denied agency to its governments using similar arguments than ALBA.

Up to the election of Mauricio Macri (2015), Argentina was not attracted by the "convergence in diversity" proposal made by former presidents Lula (Brazil) and Ricardo Lagos (Chile) in 2014. Though Halperin (2016, p. 10) thinks that it was a Brazilian ruse to gain time and dissuade other MERCOSUR governments from getting closer to PA, the issue became irrelevant after the political reorientation of the Brazilian government (2016) because MERCOSUR changed the light under which it evaluates MERCOSUR-PA convergence.

In promoting convergence Chilean Foreign Minister Heraldo Muñoz (2016) 
remarked that viewed from outside the lack of an effective knowledge of the potential of each Latin American nation affects all. Any bad image transmitted by one country hurts the rest. Thus, the possibility of a nation to stand out needs the simultaneous improvement of the regional image, something that convergence would help achieve.

If regionalisms express their promoting nations interests and objectives, which in Latin America were rather constant between 2003 and 2015, resistance helps understand the mutually nonacceptable features of those regional projects. In the following section, we analyse their interactions with the aim of identifying decisions that inspired changes or movements in them.

\section{II.1 MERCOSUR, ALBA, and PA}

\section{Interactions (2000-2018)}

By applying game theory, we consider regional agreements as collective rational actors under the influence of mutual perceptions. Each of those actors "critical junctions ${ }^{8 "}$ present different political options, and their decisions alter expectations inside and outside an agreement (Warren, 2010; Flexor;

\footnotetext{
8 "Critical junctions" differ from "critical junctures" because path dependence theory assumes that choices made before limit the choices open to actors, but in game theory previous actions influence future choices only if they have succeeded or failed.
}

Grisa, 2016). When Brazil reduced regional integration to South America, a three-player game developed; when PA reinserted a Latin American horizon, it became a four-player game by adding Mexico to Brazil. Venezuela, and Chile. In three-player games the possibility that two of them form a coalition against the third increases the latter's tendency to associate with others (Doubt 2000, p. 241), while four-player games present more coalition options (18 instead of 5 in three-players games) and create a more unstable environment.

MERCOSUR and ALBA bids for enlarging membership and cooperating between them influenced promotion of the PA by Chile. Its foundation became a critical junction for ALBA and MERCOSUR because PA affected ALBA's projection and offered a regional alternative for Paraguay and Uruguay -- the same way that ALBA had provided an alternative to CAN for Bolivia and Ecuador. Even before its political reorientation, Brazil endorsed convergence (2014), a decision that further weakened ALBA already suffering the effect of Chavez's death (2013). National interests, development models and governments objectives did not change but interactions became more dynamic after decisions made at critical junctions (See Table 1). 
Table 1. Mercosur-Alba-PA Interactive Game

\begin{tabular}{|c|c|}
\hline MERCOSUR-ALBA & ALBA-AP \\
\hline $\begin{array}{l}\text { Beginning of commodities/oil boom } \\
\text { Brazilian regional expansion/Argentine } \\
\text { default } \\
\text { MERCOSUR/Venezuela opposed FTAA }\end{array}$ & $\begin{array}{l}\text { Chile, Colombia, Mexico, Peru supported } \\
\text { FTAA/ALBA opposed it }\end{array}$ \\
\hline $\begin{array}{l}\text { 2004-2011 } \\
\text { Parallel Founding of SAC/UNASUR } \\
\text { and ALBA (December 2004) } \\
\text { Venezuela formally asked for entry to } \\
\text { MERCOSUR/Brazilian project to widen } \\
\text { MERCOSUR to South America }\end{array}$ & $\begin{array}{l}\text { Chile, Colombia, Peru supported } \\
\text { UNASUR } \\
\text { Individual clashes of Colombia and Mexico } \\
\text { with Venezuela } \\
\text { Venezuela left CAN (2006) and enlarged } \\
\text { ALBA } \\
\text { Founding of Pacific Arch (2007) }\end{array}$ \\
\hline $\begin{array}{l}\text { 2011-2015 } \\
\text { End of commodities/oil boom } \\
\text { MERCOSUR: Brazil/Argentina against PA; } \\
\text { Paraguay/Uruguay, observer status } \\
\text { ALBA proposed to enlarge ACE } 70 \text { to } \\
\text { MERCOSUR (2013) } \\
\text { MERCOSUR- ALBA division regarding } \\
\text { Convergence }\end{array}$ & $\begin{array}{l}\text { ALBA opposed PA } \\
\text { Convergence MERCOSUR-AP co- } \\
\text { sponsored by Brazil and Chile (2014) }\end{array}$ \\
\hline \begin{tabular}{l}
\multicolumn{4}{c}{$2015-2018$} \\
Argentina and Brazil
\end{tabular} & MERCOSUR-PA Dialogue \\
\hline
\end{tabular}

Source: Compiled by Author. Critical junctions in bold letters. 


\section{Discussion}

The solidarity and cooperation declarations of Latin American regional agreements do not disguise the fact that each one represents a sphere of influence or alliance to reach its promoter's national objectives. Venezuelan influence still centers in the Caribbean where previous governments of different political persuasions have historically looked for its nations' goodwill using oil. For Chile, PA achieves the long-standing objectives of deeper association with Andean and Asia-Pacific nations. "MERCOSUR ampliado" is part of Brazilian interest in controlling South American markets.

In general, Latin American governments use regional agreements to develop support networks, presented to voters as expressions of regional influence (Cascante, 2014). Brazil and Argentina had first promoted widening MERCOSUR with ALBA nations; in 2015-2016 their governments' political reorientation changed with what governments should MERCOSUR associate but it did not alter the role of the group as their foreign policy instrument.

In 2014 the convergence proposal context was characterized by ALBA's weakness and MERCOSUR's lack of an external policy agenda, a fact that diminished their economic potential (De María; Pereira, 2016). A loss of Venezuela's financial capacity and the founding of PA explain why Venezuela officialised its membership in MERCOSUR and converted ALBA's treaties into an ACE (Lapp 2012, p. 156). These actions implied that Venezuela could no longer aspire to become a regional power, but also encouraged PA to offer an alternative to Brazil through convergence to minimize Venezuelan influence within MERCOSUR.

Interactions altered neighbors' expectations, made them question their own projects, and changed the relative equilibrium among regionalisms -- in 2000 MERCOSUR was the most important; between 2007-2009 ALBA became the most active. But in the 2010s, MERCOSUR is trying to relaunch itself and ALBA has retreated into a defensive position, while cooperation has moved from MERCOSUR- ALBA to MERCOSURPA.

Interaction dynamics confirm that ideas lose legitimacy when the positive image of their sponsors disappear (Flexor; Grisa 2016, p. 34). International norms such as regionalism suffer fluctuations following the ebbs and flows of their promoting nations (Krampf 2013, p. 7). 


\section{Muralf}

INTERNACIONAL
Mural Internacional

V. $9 \mid$ N. 1

JAN-JUN 2018
They behave like style fashions (standards of behaviour for other people) and stop diffusing when there is a negative vision of their promoters. Political domestic instability, for example, has compromised the vision of Brazil and Venezuela as effective political actors and the diffusion of their regionalisms.

In this article, we moved the focus of analysis from a static analysis of decisions taken by regional agreements to a more process-oriented view of their interactions, identified what elements of regionalism foster neighbors' resistance and emphasized that actors' decisions affect not only their future choices but also those of other actors. By doing so, we provide additional insights on the importance of actorness by developing nations and on how to approach the study of regionalism in Latin America.

\section{Bibliography}

Alegría Castellanos, A.; Arroyo Mina, J. S. (2010) 'El conflicto colombo-venezolano y la construcción de escenarios desde la teoría de juegos', Convergencia, 17 (52), pp. 97-124. Retrieved from http://scielo.org.mx/scielo.php?script=sci_arttext\&pid=S140514352010000100005

Armstrong, B. (2010) "A Landlocked Bolivia: Disputes between Bolivia, Peru, and Chile". Writing Excellence Award Winner Paper 10. Retrieved from http:// soundideas.pugetsound.edu/cgi/viewcontent.cgi?article=1016\&context=writing_awar ds

BBC (2005) "México-Venezuela: nuevas acusaciones", November 15. Retrieved from http://news.bbc.co.uk/hi/spanish/latin_america/newsid_4437000/4437786.stm

Beeson, M. (2010) "Asymmetrical regionalism: China, Southeast Asia and uneven development”. East Asia. An International Quarterly 27 (4), pp. 329-343. Retrieved from

http://www.academia.edu/539167/Asymmetrical_regionalism_China_Southeast_Asia _and_uneven_development

Bisang, R.; Gutman, G. 2000. La oferta tecnológica de las principales cadenas agroindustriales en el MERCOSUR ampliado. Montevideo: PROCISUR-BID. 
Boskin, M. (2013) "Why does Chile prosper while neighbouring Argentina flounders?" The Guardian, November 22. Retrieved from https://theguardian.com/business/economics-blog/2013/nov/22/chile-prosperargentina-flounders

Cárdenas, E. J. (2005) "Debate sobre reforma del Consejo de Seguridad de las Naciones Unidas" Agenda Internacional 1 (4), pp. 90-98.

Cascante, C. H. (2014) "Entre bloques y discursos. Los procesos de alianza y disputa en América Latina". In Soto Acosta, W. (Ed.) Política Internacional e Integración Regional Comparada en América Latina. San José, Costa Rica: UNA-FLACSO, pp. $35-44$.

Cisneros, E. 2005. "Debate sobre reforma del Consejo de Seguridad de las Naciones Unidas". Agenda Internacional 1 (4), pp. 117-122.

Colombo, S. (2011) La inserción internacional de Argentina durante la presidencia de Néstor Kirchner. Tandil: CEIPIL-UNCPBA.

Daniels, C. (2015) "The Pacific Alliance and Its Effects on Latin America" International and Comparative Law Review 37 (153), pp. 153-183. Retrieved from http://digitalcommons.lmu.edu/cgi/viewcontent.cgi?article=1723\&context=ilr

De Maria, N.; Pereira, M. E. (2016) "Estrategias de inserción internacional del MERCOSUR y la ASEAN" Revista PUCE 103, pp. 273-297.

Diamint, R. (2005) "Debate sobre reforma del Consejo de Seguridad de Naciones Unidas" Agenda Internacional 1 (4), pp. 98-103.

. (2013) "Regionalismo y posicionamiento suramericano". Revista CIDOB d’Afers Internacionals 101, pp. 55-79.

Doubt, K. (2000) Sociology After Bosnia and Kosovo. Lanham, Maryland: Rowman \& Littlefield.

Escudé, C. (2015) "Realism in the Periphery". In Dominguez, J. I.; Covarrubias, A. (Eds.) Routledge Handbook of Latin America in the World. London: Routledge, pp. 45-57. 


\section{Muralf}

INTERNACIONAL

Mural Internacional

V. $9 \mid$ N. 1

JAN-JUN 2018

35

Flemes, D.; Wehner, L. (2012) "Drivers of Strategic Contestation in South America". GIGA Working 207. Papers Retrieved from https://files.ethz.ch/isn/153968/wp207_flemes-wehner.pdf

; Wojczewski, T. (2011) "Contested Leadership in Comparative Perspective". Asian Journal of Latin American Studies 24 (1), pp.1-27.

Flexor, G.; Grisa, C. (2016) "Contention, ideas, and rules: the institutionalization of family farm policy in Brazil". Canadian Journal of Latin American and Caribbean Studies 41 (1), pp.23-37.

Flisfisch, A. (2011) "La política exterior chilena y América del Sur" Estudios Internacionales 43 (168), pp. 115-141. doi:10.5354/0719-3769.2011.14342

Giacalone, R. (2008) "Motivaciones políticas para la constitución de la CSN", in: Giacalone, R. (Ed.) La integración sudamericana: Un complejo proceso inconcluso. Mérida: FACES-ULA, pp. 19-49.

. (2013) "Cambios en el regionalismo sudamericano por la proyección global de Brasil”. Aldea Mundo 36, pp. 9-21.

Girvan, N. (2008) "ALBA, PetroCaribe and CARICOM: Issues in a New Dynamic". Retrieved from http://normangirvan.info/wp-content/uploads/2009/03/albapetrocaribe-and-caricom.pdf

Halperin, M. (2016) "Ficciones de integración económica en los países de MERCOSUR". Boletín Integrar 96, pp. 2-21. Retrieved from http://20.iadb.org/intal/catalogo/PE/2016/16135.pdf

Illera, O. (2005). "La política exterior de Chávez: Proyección de la revolución bolivariana en las relaciones internacionales". Desafíos 12, pp. 209-240.

Jarroud, M. (2014) "Natural Gas - Both Crisis and Solution in Chile". Terramérica May 15, June 16. Retrieved from http://ipsnews.net/2014/06/natural-gas-crisissolution-chile/

Kornblith, M. (2004) "Percepciones venezolanas sobre la crisis de Colombia". Colombia Internacional 60, pp. 124-153. Retrieved from https://colombiainternacional.uniandes.edu.co/view.php/444/1.php 
Krampf, A. (2013) "The Life Cycles of Competing Policy Norms". KFG Working Paper 49. Berlin: Kolleg-Forschergruppe (KFG), Freie Universität. Retrieved from http://transformeurope.eu

Lapp, N. (2012). "Resistance is Util (Useful): Responses to Brazilian Hegemony". In Williams, K. P.; Lobell, S. E.; Jesse, N. G. (Eds.) Beyond Great Powers and Hegemons. Stanford, California: Stanford University Press, pp. 145-160.

Malamud, A. (2016) "El malentendido latinoamericano". Nueva Sociedad 266. http://nuso.org/articulo/el-malentendido-latinoamericano/

Milanese, J. P. (2007) "Epicentros de inestabilidade regional: La política externa da Colombia e da Venezuela no inicio do Século XXI". Relações Internacionais 13, pp. 55-71.

Retrieved

from

https://academia.edu/21842257/Epicentros_de_instabilidade_regional_a_politica_ext erna_da_Colombia_e_da_Venezuela_no_inicio_do_seculoXXI

Manger, M. S. (2009) Investing in Protection. Cambridge: Cambridge University Press.

Muhr, T. (2010) "Nicaragua: Constructing the Bolivarian Alliance for the Peoples of Our Americas (ALBA)". In Schuerkens, U. (Ed.) Globalization and Transformation of Social Inequity. London: Routledge, pp. 115-133.

Mullins, M. (2006) In the shadows of the generals. Foreign policy making in Argentina, Brazil, and Chile. London: Ashgate.

Muñoz, H. (2016) "Chile, Canada, and the Global Scenario (Speech by Chilean Foreign Minister in Ottawa)" Medium (April). Retrieved from http://canada2020.ca/chile-canada-and-the-new-global-scenario/

Narvaez, A. (2015) "Mercosur and the Pacific Alliance: Latin America Divided", May 26. Retrieved from http://www.worldpress.org/article.cfm/Mercosur-andPacific-Alliance-Latin-America-Divided.

Nolte, D. (2016) "The Pacific Alliance: Nation-Branding through Regional Organizations". GIGA Focus/Latin America, August 4 Retrieved from https://gigahamburg.de/en/system/files/publications/gf_lateinamerika_1604.pdf 


\section{Muralf}

INTERNACIONAL

Mural Internacional

V. $9 \mid$ N. 1

JAN-JUN 2018

Northouse, P. (2001). Leadership Theory and Practice. Thousand Oaks, California: Sage Publications.

O’Connor, E. (2010). "El neodesarrollismo brasileño como propuesta de desarrollo para Argentina”. Economic Studies of International Development 10 (2), pp. 55-80.

“Origen del conflicto México-Venezuela" (2005) La Jornada, November 11. Retrieved from http://dossierpolitico.com/vernoticiasanteriores.php?artid=4305\&relacion=dossierpoli tico

Pinheiro, L.; Gaio, G. (2014) "Cooperation for Development, Brazilian Regional Leadership and Global Protagonism”. Brazilian Political Science Review, 8(2), pp. 830. Retrieved from http://scielo.br/pdf/bpsr/v8n2/1981-3821-bpsr-8-2-0008.pdf

Prys, M. (2010) "Hegemony, Domination, and Detachment: Differences in Regional Powerhood". International Studies Review 12(4), pp. 479-504. DOI: 10.1111/j.14682486.2010.00957.x

Quintanar, S. (2012). "Convergencias y divergencias en las estrategias de integración y cooperación energética de Venezuela y Brasil", in: Bernal-Meza, R.; Quintanar, S. (Eds.) Regionalismo, orden mundial: Suramérica, Europa, China. Buenos Aires: GEL, pp. 241-283.

REUTERS/EFE (2006). "La propuesta para unir la CAN y el MERCOSUR divide la Cumbre Sudamericana de Bolivia". El Mundo, October 12. Retrieved from http://elmundo.es/elmundo/2006/12/09/internacional/1165690075.html

Roca, M. (2009) “América del Sur. Integración Militar". Revista DEF 44 (Buenos Aires).

Sanahuja, J. A. (2010). "Regionalismo, cooperación y liderazgos en Sudamérica. El Consejo de Defensa de Unasur". Atenea 17 (Madrid).

Schiff, M. (2002). "Chile's Trade Policy". Santiago de Chile: Banco Central de Chile Working Paper 101. Retrieved from http://si2.bcentral.cl/public/pdf/documentostrabajo/pdf/dtbc151.pdf 
SELA (2013) Acuerdo de Cooperación Energética Petrocaribe. Caracas: SELA, SPDi No. 4-13.

(2014) Evolución de la Alianza Bolivariana para los Pueblos de Nuestra América- Tratado de Comercio de los Pueblos. Caracas: SELA, SP-Di No. 4-14.

Torrijos Rivera, V. (2009) "Colombia, las FARC y la legítima defensa" Revista Política y Estrategia (Bogotá) 113, pp. 175-190.

Van Klaveren, A. (1998). "Inserción internacional de Chile”. In Toloza, C.; Lahera, E. (Eds.). Chile en los noventa. Santiago de Chile: Presidencia de la República.

Venezuela. MRE. (2006). Libro Amarillo correspondiente al Ejercicio Fiscal del Año 2005. Caracas: Ministerio de Relaciones Exteriores

Vieira, M. A.; Alden, C. (2011). "India, Brazil, and South Africa". Global Governance 17, pp. 507-528.

Warren, T. C. (2010) "The geometry of security: Modelling interstate alliances as evolving networks" Journal of Peace Research 47 (6), pp. 607-709. 